\title{
PENGGUNAAN HURUF KAPITAL PADA KARANGAN NARASI SISWA KELAS VII SEKOLAH MENENGAH PERTAMA MUHAMMADIYAH 17 CIPUTAT
}

\author{
Fatimah \\ Universitas Indraprasta PGRI Jakarta \\ 087784814086 \\ fatimahifat4@gmail.com \\ As'ad \\ Universitas Indraprasta PGRI Jakarta \\ 085770747855 \\ asadptnu@gmail.com
}

Received April 10, 2020, Revised June 11, 2020, Approved June 16, 2020

\begin{abstract}
ABSTRAK
Penelitian ini dilatarbelakangi karena masih banyaknya kesalahan penulisan huruf kapital yang dilakukan siswa kelas VII SMP Muhammadiyah 17 Ciputat pada saat menulis karangan narasi. Penelitian ini bertujuan untuk mengetahui tingkat kesalahan penggunaan huruf kapital pada karangan narasi siswa kelas VII SMP Muhammadiyah 17 Ciputat. Metode yang digunakan dalam penelitian ini adalah metode deskripsi dan metode observasi. Penggunaan huruf kapital yang akan dibahas adalah tingkat ketepatan penggunaan huruf kapital sesuai dengan Pedoman Umum Ejaan Bahasa Indonesia (PUEBI). Diperoleh hasil bahwa tingkat ketepatan penggunaan huruf kapital yang sesuai Pedoman Umum Ejaan Bahasa Indonesia (PUEBI) secara umum berada pada tingkat cukup baik (41--60) tepatnya 58,2\% yang sesuai dengan Pedoman Umum Ejaan Bahasa Indonesia (PUEBI).
\end{abstract}

\section{Kata Kunci: Huruf Kapital, Karangan Narasi, Siswa}

\begin{abstract}
This research is motivated because there are still many mistakes in writing capital letters made by students of class VII Ciputat Muhammadiyah 17 Junior High School when writing narrative essays. This study aims to determine the level of error in the use of capital letters in the narrative essay of VII grade students of SMP Muhammadiyah 17 Ciputat. The method used in this research is the description method and the observation method. The use of capital letters that will be discussed is the level of accuracy of the use of capital letters according to the General Guidelines for Indonesian Spelling (PUEBI). The results show that the level of accuracy of the use of capital letters in accordance with the General Guidelines for Indonesian Spelling (PUEBI) in general is at a fairly good level (41-60) to be exact $58.2 \%$ in accordance with the General Guidelines for Indonesian Spelling (PUEBI).
\end{abstract}

Keywords: Capital Letter, Narrative Essay, Students

\section{PENDAHULUAN}

\section{Latar Belakang}

Seseorang yang akan menulis karangan harus menguasai unsur bahasa tulis dan unsur lisan karena penguasaan kedua unsur tersebut saling berkaitan dan dapat mempermudah penulis 
Jurnal Pujangga Volume 6, Nomor 1, Juni 2020

ISSN P 2443-1478

ISSN E 2443-148

dalam menulis karangan deskripsi. Dalam penelitian ini, unsur tulis yang dianalisis adalah huruf kapital. Huruf kapital adalah huruf yang berukuran dan berbentuk khusus, biasanya digunakan sebagai huruf pertama dari kata pertama dalam kalimat. Jika penggunaan huruf kapital digunakan secara benar, suatu karangan atau wacana akan terlihat sangat baik dan benar. Penulisan huruf kapital merupakan bagian dasar dari ejaan yang disempurnakan, yakni bagian dari pemakaian dan penulisan huruf. Penggunaan huruf kapital sangat berpengaruh pada karangan karena kesalahan penggunaan huruf kapital dapat mempengaruhi penulisan karangan.

Sering dijumpai saat mencermati karangan dengan penuh ketelitian bahwa dalam karangan tersebut ternyata penulisan kaidah bahasa dan pengguanaan huruf kapital sering diabaikan oleh para siswa. Contoh, penggalan kalimat siswa dalam karangan narasi yang dibuat oleh ananda Rika kelas VII sebagai berikut:

a. Penggunaan huruf kapital pada nama daerah.

1) Api melalap habis rumah dan toko di daerah kalibata.

Penggunaan huruf kapital di atas salah, seharusnya penulisan huruf "k" pada kata "kalibata" menggunakan huruf kapital karena merupakan nama daerah, yaitu di dalam Pedoman Umum Ejaan Bahasa Indonesia (PUEBI) disebutkan "huruf kapital dipakai sebagai huruf pertama pada nama daerah”. Kalimat pengguanaan huruf kapital di atas seharusnya.

2) Api melalap habis rumah dan toko di daerah Kalibata.

b. Pengunaan huruf kapital pada nama hari.

1) Pada hari minggu sore, deburan ombak kecil yang saling berkejaran membuat suasana semakin hangat.

Penulisan huruf kapital di atas keliru, seharusnya penulisan huruf "m" pada kata "minggu" menggunakan huruf kapital karena kata Minggu merupakan nama hari, di dalam PUEBI disebutkan bahwa "huruf kapital dipakai sebagai huruf pertama nama hari, kalimat penggunaan huruf kapital di atas seharusnya.

2) Pada hari Minggu sore, deburan ombak kecil yang saling berkejaran membuat suasana semakin hangat.

Dengan pengunaan huruf kapital yang tepat, suatu tulisam atau karangan, menjadi jelas dibaca dan mudah dimengerti oleh orang yang membacanya. Menyadari hal itu peneliti merasa bahwa penguasaan pengguanaan huruf kapital perlu mendapat perhatian serius dari para ahli dan guru bahasa agar sebagai referensi dan acuan dalam pengajaran bahasa Indonesia.

Oleh karena itu, peneliti tertarik untuk melakukan penelitian yang berkaitan dengan kemampuan siswa dalam menulis karangan narasi dan penggunaan huruf kapital. Peneliti ingin 
Jurnal Pujangga Volume 6, Nomor 1, Juni 2020

ISSN P 2443-1478

ISSN E 2443-148

mengetahui kemampuan siswa kelas VII Sekolah Menengah Pertama Muhammadiyah 17 Ciputat dalam menggunakan huruf kapital pada menulis karangan narasi.

\section{Rumusan Masalah}

Berdasarkan latar belakang masalah pada studi ilmiah yang telah dikaji oleh peneliti, rumusan masalah penelitian sebagai berikut.

a. Bagaimana penggunaan huruf kapital pada penulisan karangan narasi siswa kelas VII SMP Muhammadiyah 17 Ciputat?

b. Bagaimana kendala siswa kelas VII SMP Muhammadiyah 17 Ciputat dalam menggunakan huruf kapital dalam karangan narasi?

c. Bagaimana tingkat kesalahan penggunaan huruf kapital dalam karangan narasi siswa kelas VII SMP Muhammadiyah 17 Ciputat?

d. Bagaimana tingkat ketepatan huruf kapital sesuai Pedoman Umum Ejaan Bahasa Indonesia (PUEBI) pada karangan narasi yang dibuat siswa kelas VII SMP Muhammadiyah 17 Ciputat?

\section{Tujuan Penelitian}

Tujuan penelitian ini secara praktis adalah untuk menginformasikan adanya tingkat ketepatan penggunaan huruf kapital yang masih ada di batas sedang. Selain itu, untuk memberikan referensi mengenai kaidah penggunaan bahasa Indonesia dalam penulisan karangan narasi dan sesuai Pedoman Umum Ejaan Bahasa Indonesia (PUEBI).

Penelitian ini secara operasional bertujuan untuk mengetahui penggunaan huruf kapital pada karangan narasi siswa dan memberikan studi lebih lanjut tentang aturan Pedoman Umum Ejaan Bahasa Indonesia (PUEBI).

\section{Tinjauan Pustaka}

\section{Huruf Kapital}

Menurut Kridalaksana (2001:89) "Huruf adalah tanda aksara dalam tata tulis yang merupakan anggota abjad yang melambangkan bunyi bahasa." Huruf kapital adalah huruf yang ditulis dengan huruf besar pada awal kalimat dan pada akhir kalimat yang kita bubuhkan tanda titik (Effendi, 2010:179).

Secara harfiah huruf kapital tidak hanya ada di awal kalimat saja, tetapihal ini diperkuat oleh pendapat Arifin (2008:175), "huruf kapital adalah huruf yang digunakan sebagai huruf 
pertama kalimat berupa petikan langsung, huruf pertama dalam ungkapan yang berhubungan dengan nama Tuhan dan kitab suci termasuk kata ganti-Nya, huruf pertama nama gelar, jabatan, dan pangkat yang diikuti nama orang, nama bangsa, suku dan bahasa, nama tahun, bulan, hari, hari raya, dan peristiwa sejarah, nama khas geografi, resmi badan, lembaga pemerintahan, ketatanegaraan, serta nama dokumen resmi, nama buku, majalah, surat kabar, dan judul karangan, singkatan nama gelar dan sapaan, serta kata penunjuk hubungan kekerabatan.”

Keindahan sebuah kalimat, maupun paragraf terlihat dari penggunaan Pedoman Umum Ejaan Bahasa Indonesia (PUEBI) yang sesuai dan benar, salah satunya huruf kapital. Menurut Sadikin (2014:12) huruf kapital dalam Tata Bahasa Indonesia biasa digunakan seperti berikut.

a. Huruf kapital dipakai sebagai huruf pertama kata pada awal kalimat

Misalnya:

Dia mengantuk.

Pekerjaan itu belum selesai.

b. Huruf kapital dipakai sebagai huruf pertama petikan langsung Misalnya:

Adik bertanya, "Kapan kita pulang?"

Bapak menasihatkan, "Berhati-hatilah, Nak!"

"Kemarin engkau terlambat, katanya."

c. Huruf kapital dipakai dalam ungkapan yang berhubungan dengan nama Tuhan dan kitab suci, termasuk kata ganti untuk Tuhan.

Misalnya:

Allah Alkitab Islam

Yang Mahakuasa Quran Kristen

Tuhan akan menunjukan jalan yang benar kepada hamba-Nya

d. Huruf kapital dipakai sebagai huruf pertama nama gelar kehormatan, keturunan, dan keagamaan yang diikuti nama orang.

Misalnya:

Mahaputra Yamin

Sultan Hasanudin

Haji Agus Salim 
e. Huruf kapital tidak dipakai sebagai huruf pertama gelar kehormatan, keturunan, dan keagamaan yang tidak diikuti nama orang.

Misalnya:

Dia baru saja diangkat sebagai sultan.

Tahun ini dia pergi naik $h$ aji.

f. Huruf kapital dipakai sebagai huruf pertama unsur jabatan yang diikuti nama orang, nama instansi, atau nama tempat yang digunakan sebagai pengganti nama orang tertentu.

Misalnya:

Wakil Presiden Jusuf Kalla

Gurbernur Jawa Tengah

Profesor Supomo

g. Huruf kapital dipakai sebagai huruf pertama unsur-unsur nama orang.

Misalnya:

Amir Hamzah

Susilo Bambang Yudhoyono

Anies Baswedan

h. Huruf kapital tidak dipakai huruf pertama nama orang yang digunakan sebagai nama jenis atau satuan ukuran.

Misalnya:

Mesin diesel

10 volt

5 ampere

i. Huruf kapital dipakai sebagai huruf pertama nama bangsa, suku bangsa dan bahasa.

Misalnya:

bangsa Indonesia

bahasa Sunda

suku Dayak 
ISSN P 2443-1478

ISSN E 2443-148

j. Huruf kapital tidak dipakai sebagai huruf pertama namabangsa, suku, dan bahasa yang dipakai sebagai bentuk dasar kata turunan.

Misalnya:

mengindonesiakan kata asing

keinggris-inggrisan

k. Huruf kapital dipakai sebagai huruf pertama nama tahun, bulan, hari, hari raya, dan peristiwa sejarah.

Misalnya:

bulan Agustus

hari Natal

bulan Maulid

perang Candu

hari Gulungan

tahun Hijriah

Proklamasi Kemerdekaan Indonesia

1. Huruf kapital tidak dipakai sebagai huruf pertama peristiwa sejarah yang tidak dipakai sebagai nama.

Misalnya:

Soekarno dan Hatta memproklamasikan kemerdekaan bangsanya

Perlombaan senjata membawa resiko pecahnya

perang dunia

m. Huruf kapital dipakai sebagai huruf pertama geografi.

Misalnya:

Asia Tenggara

Bukit Barisan

Cirebon

Danau Toba

n. Huruf kapital tidak dipakai sebagai huruf pertama istilah geografi yang tidak dipakai menjadi unsur nama diri.

Misalnya:

Berlayar ke teluk

Mandi di kali 
Menyebrangi selat

o. Huruf kapital tidak dipakai sebagai huruf pertama nama geografi yang dipakai sebagai nama jenis.

Misalnya:

garam inggris

kacang bogor

pisang ambon

p. Huruf kapital dipakai sebagai huruf pertama semua unsur nama negara, lembaga pemerintahan dan ketatanegaraan, serta nama dokumen resmi kecuali kata seperti dan.

Misalnya:

Republik Indonesia

Majelis Permusyawaratan Rakyat

Dapartemen Pendidikan Kebudayaan

q. Huruf kapital tidak dipakai sebagai huruf pertama kata yang bukan resmi negara, lembaga pemerintah dan ketatanegaraan, badan, serta nama dokumentasi resmi.

Misalnya:

Menjadi sebuah republik

Beberapa badan hukum

Kerjasama antara pemerintahan dan rakyat

r. Huruf kapital dipakai sebagai huruf pertama setiap unsur bentuk ulang sempurna yang terdapat padanama badan, lembaga pemerintahan, dan ketatanegaraan, serta dokumen resmi.

Misalnya:

Perserikatan Bangsa-Bangsa

Undang-Undang Dasar Republik Indonesia

Rancangan Undang-Undang Kepegawaian 
s. Huruf kapital dipakai sebagai huruf pertama semua kata (termasuk semua unsur kata ulang sempurna) di dalam nama buku, majalah, surat kabar, dan judul karangan kecuali kata seperti di, ke, dari, dan, yang, untuk tidak terletak pada posisi awal.

Misalnya:

Saya telah membaca buku Dari Ave Maria ke Jalan Lain ke Roma

Bacalah majalah Bahasa dan Sastra

Dia adalah agen surat kabar Sinar Pembangunan

t. Huruf kapital dipakai sebagai huruf pertama unsur singkatan nama gelar, pangkat, dan sapaan.

Misalnya:

Dr. Doktor

Prof. Profesor

Tn. Tuan

S.Pd. $\quad$ sarjana pendidikan

u. Huruf kapital dipakai sebagai huruf pertama kata penunjuk hubungan kekerabatan seperti, bapak, ibu, saudara, kakak, dan paman yang dipakai dalam penyapaan dan pengacuan.

Misalnya:

“Kapan Bapak berangkat?” tanya Harto.

Adik bertanya, "Itu apa, Bu?"

Surat Saudara sudah saya terima.

v. Huruf kapital tidak dipakai sebagai huruf pertama kata penunjuk hubungan kekerabatan yang tidak dipakai dalam pengacuan atau penyapaan.

Misalnya:

Kita harus menghormati bapak dan $i$ bu kita.

Semua kakak dan $a$ dik saya sudah berkeluarga.

Kemarin paman saya baru saja pergi.

w. Huruf kapital dipakai sebagai huruf pertama kata ganti anda.

Misalnya: 
Jurnal Pujangga Volume 6, Nomor 1, Juni 2020

ISSN P 2443-1478

ISSN E 2443-148

Sudahkah Anda tahu?

Surat Anda telah kami terima.

Kesehatan Anda sedang menurun.

x. Huruf kapital dipakai sebagai huruf pertama singkatan nama orang yang digunakan sebagai nama jenis atau satuan ukuran.

Misalnya:

Pascal second : Pas

$\mathrm{J} / \mathrm{K}$ atau JK-1 : Joule per Kelvin

$\mathrm{N} \quad$ : Newton

\section{Karangan Narasi}

Menurut Finoza (2009: 222) karangan narasi (berasal dari narration= bercerita) adalah suatu bentuk tulisan yang berusaha menciptakan, mengisahkan, merangkaikan tindak-tanduk perbuatan manusia dalam sebuah peristiwa secara kronologis atau yang berlangsung dalam kesatuan waktu.Menurut Kuntarto (2009: 222) narasi adalah suatu bentuk karangan yang berusaha menggambarkan dengan sejelas-jelasnya kepada pembaca tentang peristiwa pada suatu waktu kepada pembaca. Hal terpenting dalam karangan narasi adalah unsur tindakan atau buatan sehingga ketika membaca karangan narasi pembaca seolah-olah melihat atau mengalami sendiri peristiwa itu. Terdapat dua bentuk narasi, yaitu narasi sugestif dan narasi ekspositoris.

Narasi sugestif atau imajinatif merupakan suatu rangkaian peristiwa yang disajikan sedemikian rupa sehingga merangsang daya khayal para pembaca. Melalui narasi sugestif kita dapat menyampaikan peristiwa pada suatu waktu dengan makna yang tersirat atau tersurat dengan bahasa yang lebih condong ke bahasa figuratif dengan menitikberatkan penggunaan katakata konotatif. Narasi sugestif berupa wacana fiktif seperti dongeng, cerpen, novel, dan roman. Dongeng, cerpen, novel, dan roman merupakan bentuk narasi fiktif dengan ciri khas yang dimilikinya yaitu adanya alur dan suspensi, latar dan waktu, tokoh dan karakter, sudut pandang dan makna yang terkandung di dalamnya.

Berbeda dengan narasi sugestif yang menyajikan karangan dengan bahasa konotasi dan menimbulkan daya imajinasi, ekspositoris adalah bentuk karangan yang sebaliknya dari karangan narasi sugestif. Narasi ekspositoris bersifat nonfiktif yang disajikan dengan bahasa bahasa denotatif dan tujuan utama bukaan menimbulkan daya imajinasi, melainkan menambah pengetahuan pembaca dengan pemaparan rasional. Setelah membaca karangan narasi 
Jurnal Pujangga Volume 6, Nomor 1, Juni 2020

ISSN P 2443-1478

ISSN E 2443-148

ekspositoris pembaca mendapatkan pengetahuan atau informasi suatu peristiwa. Sejarah, biografi, dan autobiografi adalah bentuk narasi yanag menjelaskan peristiwa-peristiwa yang menyangkut riwayat hidup atau pengalaman perorangan atau kelompok dengan penyajian yang berusaha menarik manfaat dari pengalaman tersebut.

Berdasar pada hasil observasi di lapangan pada penelitian di bulan September--Desember 2016, diperoleh hasil tingkat ketepatan penulisan huruf kapital pada karangan narasi siswa berada pada tingkat sedang. Berikut akan disajikan hasil dan pembahasannya.

\section{METODE PENELITIAN}

Penelitian ini menggunakan metode deskripsi. Metode deskripsi yaitu metode yang berusaha memaparkan dan menggambarkan data yang diperoleh dari lapangan yang sebenarnya tentang penggunaan huruf kapital dalam karangan narasi siswa SMP Muhammadiyah 17 Ciputat. Metode observasi dilakukan dengan cara mengunjungi SMP Muhammadiyah 17 CIputat untuk mencari data tentang penggunaan huruf kapital siswa dalam karangan narasi. Populasi dalam penelitian ini adalah siswa kelas VIII sebanyak 2 kelas berjumalah 60 siswa dan sampel yang digunakan adalah sebanyak 30\% dari populasi yaitu sejumlah 18 siswa. Instrumen yang digunakan untuk pengumpulan data pada penelitian ini, yaitu menggunakan teknik tes, sehingga dari tes mengarang tersebut peneliti mendapatkan data dari responden. Dalam hal ini siswa sebagai responden dijadikan sumber data yang menunjukan kemampuan siswa dalam bidang yang diteliti.

Data yang terkumpul ditabulasikan dan dideskrpisikan dalam bentuk tabel sesuai dengan permasalahan penelitian.Setelah data dideskripsikan, kemudian data dianalisis secara terperinci dan sistematis sesuia dengan masalah penelitian dan untuk mengetahui hasil analisis penulis mengacu pada kepada rumus yang dikemukakan Sudjana (2009: 131).

$$
\frac{\mathrm{f} x}{\mathrm{~N}} 100 \%
$$

Keterangan:

f : banyaknya penggunaan (benar atau salah)

$\mathrm{N}$ : banyaknya data keseluruhan

Setelah diketahui hasil analisisnya, maka kegiatan selanjutnya yaitu menetukan kualitas penggunaan huruf kapital dengan menghubungkan rentangan nilai yang dikemukakan oleh Rohani (2004: 176) sebagai berikut:

A : kategori sangat baik (81--100) 
Jurnal Pujangga Volume 6, Nomor 1, Juni 2020

ISSN P 2443-1478

ISSN E 2443-148
B : kategori baik
$(61--80)$
C : kategori cukup baik (41--60)
D : kategori sedang
(21--40)
E : kategori kurang baik (1--20)

\section{HASIL DAN PEMBAHASAN}

\section{Pemakaian Huruf Kapital pada Karangan Narasi}

\begin{tabular}{|c|c|c|c|c|c|c|c|c|c|c|c|}
\hline \multirow{3}{*}{ No } & \multirow{3}{*}{ Paragraf } & \multicolumn{10}{|c|}{ Pemakaian Huruf Kapital } \\
\hline & & \multicolumn{5}{|c|}{ Sesuai PUEBI } & \multicolumn{5}{|c|}{$\begin{array}{c}\text { Tidak } \\
\text { Sesuai } \\
\text { PUEBI }\end{array}$} \\
\hline & & 1 & 2 & 3 & 4 & 5 & 1 & 2 & 3 & & 5 \\
\hline 1 . & $\begin{array}{l}\text { Pada tanggal } 26 \text { mei } 2019 \text { saya pergi ke taman } \\
\text { matahari. Saya berangkat dengan pak Guru dan } \\
\text { kawan-kawan. Saya pergi jam 05.00. Sebelum } \\
\text { berangkat saya dan kawan-kawan saya berdoa } \\
\text { supaya selamat di perjalanan. Pas sampai di taman } \\
\text { matahari Saya Pun turun. Udara di sana sangat } \\
\text { segar, walau cuaca tidak terlalu mendukung saya } \\
\text { cepat membeli tiket dan saya masuk. } \\
\text { Saya dan kawan-kawan pergi ke menara } \\
\text { pandang di sana seluruh taman matahari terlihat } \\
\text { dari menara pandang. Di sana saya poto-poto } \\
\text { dengan kawan-kawan. } \\
\text { Saya pergi ke rumah hantu di sana sangat gelap. } \\
\text { Saya dan teman-teman saya ketakutan karena di } \\
\text { sana banyak hantu lalu saya nyasar pas nyasar ada } \\
\text { tengkorak yg berjalan lalu saya berhasil keluar. }\end{array}$ & 10 & & & & & 1 & & & & 2 \\
\hline 2. & $\begin{array}{l}\text { Pada saat itu hari pertama sekolah. Aku dipilih } \\
\text { untuk menjadi sekertaris oleh bu rika. aku sangat } \\
\text { malu menulis di depan anak-anak/teman-teman tapi } \\
\text { jadi sekertaris itu tanggung jawabnya Besar. } \\
\text { Mengabsen anak-anak tulis di agenda tapi gak } \\
\text { papah, seneng kok. jadi sekertaris itu cape bngt. } \\
\text { Asal banyak pahalanya. Saya dulu emang ngarep } \\
\text { jadi sekertaris di SD tapi sekarang udah tercapai. }\end{array}$ & 6 & & 1 & & & 2 & & & & \\
\hline 3. & $\begin{array}{l}\text { Pada hari itu, aku mengikuti lomba panjat } \\
\text { Pinang dan kawan-kawanku dan aku paling } \\
\text { bawah dan teman-temanku saling punggung- } \\
\text { punggungnya dan aku sempat jatoh karena aku } \\
\text { keberatan karna punggungku sudah pegal dan } \\
\text { terus orang lain yg menaikinya. Tapi dia juga } \\
\text { kalah karna dia kepeleset. Nah setelah itu aku } \\
\text { yg menaikinya Pertama-tama aku yg di bawah } \\
\text { terus kawan-kawanku yg menaikinya dan } \\
\text { akhirnya aku menang. }\end{array}$ & 4 & & & & & 1 & & & & \\
\hline
\end{tabular}




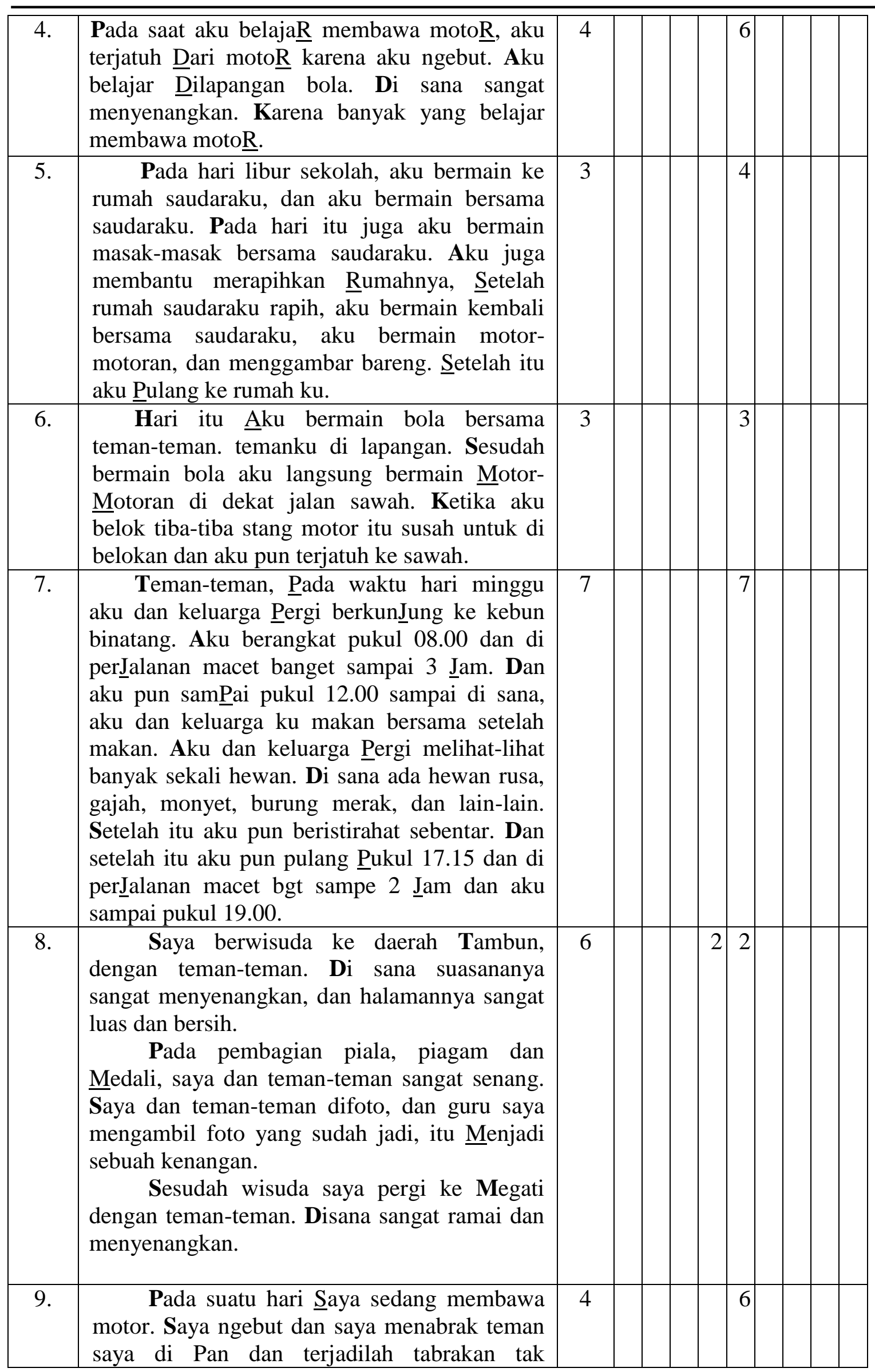




\begin{tabular}{|c|c|c|c|c|c|c|c|c|}
\hline & $\begin{array}{l}\text { terhindarkan. Dan saya langsung di bawa ke } \\
\text { rumah depan Saya di marahi dan motor } \underline{S} a y a \\
\text { rusak berapt lalu motor saya di serpis. } \\
\text { dan } \underline{S} a y a \text { berangkat sekolah dan } \underline{\text { Saya di }} \\
\text { tertawakan oleh temnku dan saya tertawa } \\
\text { berhbahak-bahak. Itulah pengalaman Saya } \\
\text { jatuh dari motor. }\end{array}$ & & & & & & & \\
\hline 10 & $\begin{array}{l}\text { Pada hari kamis tanggal } 26 \text { Mei } 2016 \\
\text { saya pergi jalan-jalan ke Taman matahari } \\
\text { bersama teman-teman. Saya berangkat pukul } \\
\text { 05.00, tapi pada waktu itu teman-teman semua } \\
\text { sudah datang semua, dan akhirnya berangkat. } \\
\text { Saat diperjalanan ada yang makan } \\
\text { cemilan, ada yang tidur. Saat di bis sangat } \\
\text { menyenangkan sekali. Kita bercanda bareng, } \\
\text { kami foto-foto di bis pokoknya } \\
\text { menyenangkan. } \\
\text { Beberapa jam kemudian akhirnya sampai } \\
\text { saya dan teman-teman saya langsung } \\
\text { berkumpul bersama dengan guru. } \\
\text { disana ada banyak wahana. saya dan } \\
\text { teman-teman saya masuk rumah hantu. hari } \\
\text { pun sudah malam kami pulang setelah } \\
\text { beberapa jam akhirnya sampai di rumah. }\end{array}$ & 4 & 1 & 1 & 4 & & & 1 \\
\hline 11 & $\begin{array}{l}\text { Dulu sekolah mengadakan study tour ke taman } \\
\text { matahari. Kita berangkat jam 08.00, aku dan } \\
\text { teman-teman di dalam bus itu bernyanyi } \\
\text { bareng, tertawa-tawa pokoknya seru deh. } \\
\text { walaupun di perjalanan kadang macet kadang } \\
\text { engga tapi tetap seru. } \\
\text { dan sesampai disana kita makan bareng pas } \\
\text { makan saya dan teman-teman menaiki perahu } \\
\text { naga, perahu karet, berangkat ke rumah hantu, } \\
\text { pergi berenang, itu semua sangat seru sekali. }\end{array}$ & 2 & & & 2 & & & 2 \\
\hline 12 & $\begin{array}{l}\text { waktu kelas } 2 \mathrm{SD} \text {, aku ikut pesantren kilat. di } \\
\text { sana ada sebuah perlombaan, dan aku } \\
\text { mengikuti perlombaan itu. Aku mengikuti } \\
\text { lomba BTQ. Teman-teman akupun banyak } \\
\text { yang ikut perlombaaan itu. ada yang ikut lomba } \\
\text { azan, praktek shalat, dan masih banyak lagi. }\end{array}$ & 2 & & & 3 & & & \\
\hline 13 & $\begin{array}{l}\text { Pada hari kamis, aku jalan-jalan ke taman } \\
\text { matahari, (b-bogor). Aku senang sekali bisa } \\
\text { jalan-jalan bersama mereka. Waktu itu aku } \\
\text { pergi dari rumah jam } 05.00 \text {. aku sudah ada di } \\
\text { bus. Aku berangkat ke taman matahari jam } \\
\text { 08.00. aku senang sekali bisa jalan-jalan sama } \\
\text { teman-teman. }\end{array}$ & 4 & & & 2 & & & 3 \\
\hline 14 & Pada suatu hari, Prince ingin menjadi & 4 & & & 1 & 1 & & \\
\hline
\end{tabular}




\begin{tabular}{|c|c|c|c|c|c|c|c|c|c|c|c|}
\hline & $\begin{array}{l}\text { youtubers. Lalu ia meminta kepada4ibunya } \\
\text { untuk membelikan peralatan youtubers. } \\
\text { Sesampainya ibu di rumah, ia langsung } \\
\text { memasang peralatan youtubers. Lepas itu, ia } \\
\text { langsung membuat video tetang dia. setelah itu, } \\
\text { prince bekerja di sebuah perusahaan digital. }\end{array}$ & & & & & & & & & & \\
\hline 15 & $\begin{array}{l}\text { Pada saat saya kondangan, saya ingin jajan dan } \\
\text { saya meminta duit kepada nenek saya. Pada } \\
\text { saat saya meminta "Nek, Saya ingin jajan. } \\
\text { Mana duitnya?" kata saya. Ternyata nenek } \\
\text { saya tidak mendengar karena dia sedang asik } \\
\text { makan. }\end{array}$ & 5 & & & & & & & 1 & & \\
\hline 16 & $\begin{array}{l}\text { Hari Sabtu pagi, aku bangun sangat pagi untuk } \\
\text { mengambil ijazah di sekolahku. Aku buru-buru } \\
\text { mandi, makan, dan langsung berangkat ke } \\
\text { sekolah dengan kakakku. dan sesampainya ke } \\
\text { Sekolah temanku-temanku sudah banyak yang } \\
\text { datang. }\end{array}$ & 2 & & & 1 & & 1 & & & & 1 \\
\hline 17 & $\begin{array}{l}\text { Pada hari itu Ibuku melarangku naik sepeda } \\
\text { keponakanku, lalu aku tidak mendengarkan } \\
\text { omongan ibuku. Lalu itu aku teruss saja } \\
\text { mengowes terus. Sehabis itu aku tidak } \\
\text { konsentrasi membawa sepeda keponakanku } \\
\text { aku tidak rem, sehingga aku terjatuh. }\end{array}$ & 3 & & & & & & & 1 & & \\
\hline \multirow[t]{2}{*}{18} & $\begin{array}{l}\text { Waktu itu aku jatuh dari sepeda karena aku } \\
\text { ngebut-ngebut. Untungnya, aku tidak menabrak } \\
\text { anak kecil, tetapi aku terjatuh karena } \\
\text { mengerem mendadak. Akupun langsung } \\
\text { mengobatinya dengan obat merah. keesokan } \\
\text { harinya, waktu aku bangun dari tidur aku } \\
\text { langsung melihat kakiku yang kemarin terjatuh, } \\
\text { ternyata kaki sudah sembuh. }\end{array}$ & 3 & & & & & 1 & - & & & \\
\hline & & 76 & - & 1 & 2 & 3 & $\begin{array}{l}4 \\
6\end{array}$ & - & 3 & 1 & 9 \\
\hline
\end{tabular}

Keterangan tabel:

B (bold) : : huruf kapital sesuai dengan Pedoman Umum Ejaan Bahasa Indonesia (PUEBI)

$\underline{\mathrm{U}}$ (underline) : huruf kapital tidak sesuai dengan Pedoman Umum Ejaan Bahasa Indonesia (PUEBI)

1: Pemakaian huruf kapital sebagai huruf pertama kata pada awal kalimat

2: Pemakaian huruf kapital dipakai sebagai huruf pertama nama gelar kehormatan, keturunan, keagamaan, yang diikuti nama orang.

3: Pemakaian huruf kapital dipakai sebagai huruf pertama unsur-unsur nama orang

4: Pemakaian huruf kapital dipakai sebagai nama tahun, bulan, hari, hari raya, dan peristiwa sejarah. 
Jurnal Pujangga Volume 6, Nomor 1, Juni 2020

ISSN P 2443-1478

ISSN E 2443-148

5: Pemakaian huruf kapital dipakai sebagai huruf pertama nama geografi (tempat).

\section{Rekapitulasi Pemakaian Huruf Kapital}

\begin{tabular}{|c|c|c|c|c|c|}
\hline \multirow{2}{*}{$\begin{array}{l}\mathrm{N} \\
\mathrm{o}\end{array}$} & \multirow{2}{*}{ Pemakaian Huruf Kapital } & \multicolumn{2}{|c|}{ Sesuai PUEBI } & \multicolumn{2}{|c|}{$\begin{array}{c}\text { Tidak Sesuai } \\
\text { PUEBI }\end{array}$} \\
\hline & & $\begin{array}{c}\text { Jumlah } \\
\text { Pemakaian }\end{array}$ & $\%$ & $\begin{array}{c}\text { Jumlah } \\
\text { Pemakaian }\end{array}$ & $\%$ \\
\hline 1. & $\begin{array}{l}\text { Pemakaian huruf kapital } \\
\text { sebagai huruf pertama } \\
\text { kata pada awal kalimat }\end{array}$ & 76 & $62,3 \%$ & 46 & $37,7 \%$ \\
\hline 2. & $\begin{array}{l}\text { Pemakaian huruf } \\
\text { dipakai sebagai hural } \\
\text { pertama nama gelar } \\
\text { kehormatan, keturunan, } \\
\text { keagamaan, yang diikuti } \\
\text { nama orang. }\end{array}$ & - & $0 \%$ & - & $0 \%$ \\
\hline 3. & $\begin{array}{l}\text { Pemakaian huruf kapital } \\
\text { dipakai sebagai huruf } \\
\text { pertama unsur-unsur nama } \\
\text { orang }\end{array}$ & 1 & $25 \%$ & 3 & $75 \%$ \\
\hline 4. & $\begin{array}{l}\text { Pemakaian huruf kapital } \\
\text { dipakai sebagai nama } \\
\text { tahun, bulan, hari, hari } \\
\text { raya, dan peristiwa } \\
\text { sejarah. }\end{array}$ & 2 & $66,7 \%$ & 1 & $33,3 \%$ \\
\hline \multirow[t]{2}{*}{5.} & $\begin{array}{l}\text { Pemakaian huruf kapital } \\
\text { dipakai sebagai huruf } \\
\text { pertama nama geografi. }\end{array}$ & 3 & $25 \%$ & 9 & $75 \%$ \\
\hline & & 82 & $\begin{array}{l}\mathbf{5 8 , 2} \\
\%\end{array}$ & 59 & $\begin{array}{c}41,8 \\
\%\end{array}$ \\
\hline
\end{tabular}

Berdasarkan deskripsi di atas, diperoleh hasil bahwa tingkat ketepatan penggunaan huruf kapital yang sesuai PUEBI secara umum berada pada tingkat cukup baik (41-60) tepatnya 58,2\% yang sesuai dengan Pedoman Umum Ejaan Bahasa Indonesia (PUEBI). Berikut rincian pemakaian huruf kapital sesuai dengan Pedoman Umum Ejaan Bahasa Indonesia (PUEBI): Pemakaian huruf kapital sebagai huruf pertama kata pada awal kalimat (62,3\%); Pemakaian huruf kapital dipakai sebagai huruf pertama nama gelar kehormatan, keturunan, keagamaan, yang diikuti nama orang. (0\%); Pemakaian huruf kapital dipakai sebagai huruf pertama unsur-unsur nama orang $(25 \%)$; Pemakaian huruf kapital dipakai sebagai nama tahun, bulan, hari, hari raya, dan peristiwa sejarah $(66,7 \%)$; Pemakaian huruf kapital dipakai sebagai huruf pertama nama geografi (25\%).

Selanjutnya, untuk penggunaan huruf kapital yang tidak sesuai PUEBI diperoleh hasil sebagai berikut: Pemakaian huruf kapital sebagai huruf pertama kata pada awal 
Jurnal Pujangga Volume 6, Nomor 1, Juni 2020

ISSN P 2443-1478

ISSN E 2443-148

kalimat 37,3(\%); Pemakaian huruf kapital sebagai huruf pertama kata nama gelar kehormatan, keturunan, keagamaan, yang diikuti nama orang. (0\%); Pemakaian huruf kapital dipakai sebagai huruf pertama unsur-unsur nama orang $(75 \%)$; Pemakaian huruf kapital dipakai sebagai nama tahun, bulan, hari, hari raya, dan peristiwa sejarah $(33,3 \%)$; Pemakaian huruf kapital dipakai sebagai huruf pertama nama geografi (75\%).

\section{PENUTUP}

\section{Simpulan}

Diperoleh hasil bahwa tingkat ketepatan penggunaan huruf kapital yang sesuai PUEBI secara umum berada pada tingkat cukup baik (41--60) tepatnya 58,2\% yang sesuai dengan Pedoman Umum Ejaan Bahasa Indonesia (PUEBI). Berikut rincian pemakaian huruf kapital sesuai Pedoman Umum Ejaan Bahasa Indonesia (PUEBI): Pemakaian huruf kapital sebagai huruf pertama kata pada awal kalimat (62,3\%); Pemakaian huruf kapital dipakai sebagai huruf pertama nama gelar kehormatan, keturunan, keagamaan, yang diikuti nama orang. (0\%); Pemakaian huruf kapital dipakai sebagai huruf pertama unsur-unsur nama orang (25\%); Pemakaian huruf kapital dipakai sebagai nama tahun, bulan, hari, hari raya, dan peristiwa sejarah (66,7\%); Pemakaian huruf kapital dipakai sebagai huruf pertama nama geografi (25\%). Penelitian ini bukan sematamata melihat tingkat ketepatan penggunaan huruf kapital pada karangan narasi siswa, namun juga diharapkan dapat melihat sejauh mana siswa memahami penggunaan kaidah bahasa Indonesia dan aturan Pedoman Umum Ejaan Bahasa Indonesia (PUEBI).

Diperoleh hasil bahwa tingkat ketepatan penggunaan huruf kapital yang sesuai dengan Pedoman Umum Ejaan Bahasa Indonesia (PUEBI) secara umum berada pada tingkat cukup baik (41--60) tepatnya 57\% yang sesuai dengan Pedoman Umum Ejaan Bahasa Indonesia (PUEBI). Berikut rincian pemakaian huruf kapital sesuai PUEBI: Pemakaian huruf kapital sebagai huruf pertama kata pada awal kalimat (58,6\%); Pemakaian huruf kapital dipakai sebagai huruf pertama nama gelar kehormatan, keturunan, keagamaan, yang diikuti nama orang. (0\%); Pemakaian huruf kapital dipakai sebagai huruf pertama unsur- unsur nama orang (100\%): Pemakaian huruf kapital dipakai sebagai nama tahun, bulan, hari, hari raya, dan peristiwa sejarah (33.3\%); Pemakaian huruf kapital dipakai sebagai huruf pertama nama geografi (50\%). 
Jurnal Pujangga Volume 6, Nomor 1, Juni 2020

ISSN P 2443-1478

ISSN E 2443-148

\section{Saran}

Penelitian ini bukan semata-mata melihat tingkat ketepatan penggunaan huruf kapital pada karangan narasi siswa, tetapi juga dapat melihat seberapa jauh siswa memahami penggunaan kaidah bahasa Indonesia dan aturan Pedoman Umum Ejaan Bahasa Indonesia (PUEBI). 


\section{DAFTAR PUSTAKA}

Arifin, E. Zaenal dan A. Amran Tasai. 2008. Cermat Berbahasa Indonesia. Edisi Revisi. Jakarta: Akademia Pressindo. 2010. Cermat Bahasa Indonesia. Jakarta: Pustaka Mandiri.

Arifin, E. Zaenal, dkk. 2014. Pengembangan dan Pembinaan Bahasa; pada Era Teknologi Informasi. Jakarta: Pusaka Mandiri.

Badan Pengembangan dan Pembinaan Bahasa Kementerian Pendidiikan dan Kebudayaan. 2011. Undang-Undang Republik Indonesia Nomor 24 Tahun 2009 tentang Bendera, Bahasa, dan Lambang Negara, serta Lagu Kebangsaan. Jakarta.

Effendi, S. 2015. Tata Bahasa Materi Bahasa Indonesia. Jakarta : Rosda.

Finoza, Lamuddin. 1999. Komposisi Bahasa Indonesia. Jakarta: Diksi Insan Mulia

Kridalaksana, Harimurti. 2007. Pembentukan Kata dalam Bahasa Indonesia. Jakarta : Gramedia.

Sudjana, Nana. 2012. Penelitian dan Penilaian Pendidikan. Solo : Sinar Baru Algensindo.

Setyawati, Nanik. 2010. Analisis Kesalahan Berbahasa Indonesia: Teori dan Praktik. Surakarta: Yuma Pustaka.

Sodikin, Muhammad. 2019. Bahasa Indonesia untuk Perguruan Tinggi. Jakarta Mitra Wacana Media.

Wridah, Ernawati. 2008. EYD dan Seputar Kebahasa-Indonesiaan. Jakarta: Kawan Pustaka.

Jurnal Kreativitas Vol. 3 No. 1 Januari 2014, 17--28, perpusnas.go.id, (diakses tanggal 9 Desember 2015)

http//:www.elib.unikom.ac.id, (diakses tanggal 9 Desember 2015).

http//: www.eprints.upnjatim.ac.id, (diakses tanggal 9 Desember 2015).

badanbahasa.kemdikbud.go.id.PUEBI (diakses tanggal 28 November 2016). 